\title{
TINGKAT STRES PERAWAT KRITIS BERDASARKAN UNIT, POSISI, DAN JENJANG KARIR RUMAH SAKIT ADVENT BANDUNG
}

\section{LEVEL STRESS OF NURSES IN THE CRITICAL STRESS UNDER THE UNIT, pOSITION, AND LEVELS OF CAREER ADVENT HOSPITAL BANDUNG}

\author{
Susi Susanti ${ }^{1}$, Gilny Aileen Joan ${ }^{2}$, Denny Ricky ${ }^{3}$
}

Fakultas IImu Keperawatan Universitas Advent Indonesia

Email: siahaansusi@gmail.com

\begin{abstract}
ABSTRAK
Pendahuluan: Stres kerja pada perawat dapat terjadi jika perawat yang bertugas mendapatkan beban kerja yang melebihi kemampuannya sehingga perawat tidak mampu memenuhi atau menyelesaikan tugasnya. Metode: Metode yang digunakan kuesioner dengan Total-Sampling, insfrumen yang digunakan kuesioner Depresion Anxiety Stress Scale (DASS) yang terdiri dari 42 petanyaan. Hasil: Perolehan data tingkat stress perawat berdasarkan unit, poisisi, dan jenjang karir dihitung menggunakan rumus mean, hasil uji statistik pearson rho tingkat stres perawat berdasarkan unit, posisi, dan jenjang karir yang signifikan dengan tingkat stress, tingkat stress tertinggi di unit IGD dengan tingkat sfres berat $(30,62)$ dan tingkat stress terendah adalah tingkat stress di Unit NICU ringan (14,07). Hasil penelitian in menunjukkan tingkat stress tertinggi di posisi supervisior dengan tingkat stress sedang $(24,67)$ dan tingkat stress terendah adalah head nurse dengan tingkat stress sedang $(19,94)$ sedangkan tingkat stress tertinggi berdasarkan jenjang karir lama kerja 1-5 tahun mengalami tingkat stress yang berat $(25,59)$ dan tingkat stress terendah yaitu jenjang karir 1115 tahun mengalami tingkat stress ringan. Diskusi: Membuat sfrategi untuk mengurangi dapak stress yang timbul pada perawat yang bekerj di tuang perawatan kritis.
\end{abstract}

Kata Kunci: Jenjang karir, Tingkat stres, Unit, Posisi

\begin{abstract}
Introduction: Job stress on caregivers can occur if the nurse on duty get a workload that exceeds his ability so that nurses are not able to fulfill or complete the task Methods: The method used by Total-sampling questionnaire, the instrument used questionnaire Depression Anxiety Stress Scale (DASS), which consists of 42 petanyaan. Results: Acquisition of data stress levels ofnurses based unit, poisisi, and a career path is calculated using the mean, the statistical test ofPearson's rho stress levels of nurses based units, positions and careers with significant levels of stress, the stress levels of the highest in unit IGD level severe stress (30.62) and the lowest stress level is the level ofstress in the NICU Unit lightweight (14.07). The results showed the highest stress level in position supervisior with moderate stress levels (24.67) and the lowest stress level is a head nurse with moderate stress levels (19.94), while the highest stress level is based on a long career 1-5 years work experience level severe stress (25.59) and the lowest stress levels are 11-15 years career experience mild stress level. Discussion: Make dapak strategies to reduce the stress that arises in the bekerj nurses in critical care room.
\end{abstract}

Keywords: Career, Position, Stress Level, Unit
JURNAL

SKOLASTIK KEPERAWATAN

Vol. 2, No.2

Juli - Desember 2016

ISSN: $2443-0935$

E-ISSN: 2443 - 1699 


\section{PENDAHULUAN}

Stres kerja adalah suatu respon penyesuaian seseorang terhadap berbagai tuntutan yang bersumber dari dalam ataupun dari luar individu yang dirasakan sebagai ancaman (Nur, 2013). Stres kerja pada perawat dapat terjadi jika perawat yang bertugas mendapatkan beban kerja yang melebihi kemampuannya sehingga perawat tidak mampu memenuhi atau menyelesaikan tugasnya. Selain itu, stress kerja perawat dapat pula disebabkan oleh karena jenis penyakit pasien, pengkajian pasien, dan lingkungan pasien yang menimbulkan masalah dalam tuntutan untuk menyelamatkan pasien (Levin et al., 2004).

European Agency For an Health at Work (2009) menunjukan bahwa perawat memiliki prevalensi stres yang tinggi berhubungan dengan pekerjaan. The Daily (2007) menemukan bahwa dua pertiga, atau $67 \%$ dari kepala perawat dan supervisor perawat dilaporkan mengalami su•es kerja yang tinggi dari pekerjaannya. Bahkan ketika pengaruh dari luar pekerjaan diperhitungkan, perawat dan dokter secara signifikan lebih mungkin untuk mengalami stress kerja yang tinggi dibandingkan dengan semua petugas kesehatan lainnya. Pengaruh luar pekerjaan yaitu, perkawinan, problem orangtua, hubungan interpersonal, lingkunganhidup, hukum, perkembangan, penyakit fisik atau cidera, factor keluarga, dan lain-lain.

Murray (2012) mengatakan bahwa perawat adalah salah satu profesi yang beresiko tinggi mengalami stress terutama perawat yang bekerja di perawatan kritis. Hal ini disebabkan oleh karena perawat memilki tugas dan tanggungjawab yang sangat tinggi, rotasi penggantian pasien, kasus yang akut, penggunaan alat bantu yang rumit dan akurasi yang tepat, pengawasan yang tepat terhadap keselamatan nyawa manusia.

Murhayati (2010) mengatakan bahwa salah satu stesor perawat di ruang kritis adalah lituntutnya keterampilan dalam mengambil keputusan yang cepat dan tepat. Perawat banyak menggunakan waktunya untuk berinteraksi dengan teman sejawat, tenagakerja, pasien, sertalingkungannya sehingga dapat mempengaruhi perasaan seperti marah, malu, kecewa, bingung, takut dan frustasi karena tidak menemukan jalan keluar terhadap maslah pasien. Apabila tuntutan permasalahan tersebut tidak dapat diselesaikan perawat dapat mengalami stress berat, kehilangan motivasi, mengalami kejenuhan yang berat.

Teori Patricia Benner yang di adaptasi model Dreyfus menjelaskan, teori ini dapat menjadi pedoman untuk praktek keperawatan kritis. Ada lima tingkatan pembangunan dalam karir perawat yaitu: novice, advance beginner, competent, proficient, expert (Wolf et al.,2012).

Lama kerja dapat menimbulkan perbedaan fngkat sfres. Tidak semua yang bekerja di perawatan dalam waktu yang lama mengalami tingkatan stres yang sama. Perawat yang baru bekerja di ruang perawatan kritis mengalami tingkat sfres yang tingö. Hal ini disebabkan karena perawat memilki sedikit pengalaman dalam merawat klien kritis (Ivancevich; Konopaske; Mattesson,2007). Lokasi kerja dirumah sakit dengan beban kerja yang berat dan monoton serta mempunyai resiko yang tinggi adalah di ruang perawatan kritis Ruang perawatan kritis terdiri dari Intencive Care Unit (ICU), High Care Unit (HCU), Neonatal Intensive Care Unit (NICU), Instalasi Gawat Darurat (IGD), dimana perawat sering mengalami stress akibat tanggung jawab yang lebih besar dibandingkan dengan perawat bagian lain.

\section{BAHAN DAN METODE}

Desain penelitian ini menggunakan metode deskriptif kolerasi. Metode deskriptif kolerasi adalah suatu metode penelitian yang dilakukan dengan tujuan utama untuk membuat gambaran atau deskriptif tentang hubungan antara dua fenomena atau lebih (Sugianto 2003:84). Penelitian ini merupakan deskriptif kolerasi yang bertujuan untuk memperoleh gambaran hubungan 
tingkat stress perawat di ruang kritis dengan unit, posisi, dan jenjang karir di Rumah Sakit Advent Bandung. Populasi adalah setiap subjek yang memenuhi kriteria yang telah ditetapkan (Nursalam 2008:89). Populasi yang digunakan dalam penelitian ini adalah perawat yang bekerja di ruang perawatan kritis Rumah Sakit Advent Bandung. Sugiono(2010:61) menjelaskan bahwa populasi adalah wilayah yang terdiri atas objek, subjek yang mempunyai kualitas dan karakteristik tertentu yang ditetapkan dan kemudian ditarik kesimpulannya. Peneliti ini menggunakan total sampling dan menentukan sendiri kiriteria-kriteria yang pada populasi yang diteliti. Populasi yang digunakan dalam penelitian adalah 76 perawat, dan yang ikut dalam penelitian ini adalah 69 perawat di ruang perawatan kritis Rumah Sakit Advent Bandung.

Sugiyono (2008:116) mengatakan sampel adalah sebagian dari jumlah dan karakteristik yang dimiliki oleh populasi, jika peneliti mempunyai pertimbanganpertimbangan tertentu atau penentuan sampel untuk tujuan tertentu.

Subjek dalam penelitian ini adalah: Subjek merupakan perawat yang bekerja di ruang perawatan kritis Rumah Sakit Advent Bandung, subjek merupakan perawat yang terdaftar sebagai karyawan di ruang perawatan kritis Rumah Sakit Advent Bandung, subjek secara sukarela ikut berpartisipasi dalam penelitian yang akan dilakukan ini, subjek penelitian ini melibatkan 69 perawat yang bekerja di ruang kritis Rumah Sakit Advent Bandung.

Insü•umen penelitian bertujuan untuk memperoleh data yang dibutuhkan oleh peneliti. Instrumen adalah suatu alat yang digunakan untuk mengukur suatu konsep dalam suatu riset. Sebuah insfrument dapat berupa tes tertulis dan wawancara tersfruktur. Insüumen yang digunakan dalam penelitian ini berupa kuesioner. Setiadi (2007:291) menjelaskan bahwa insfrumen yang valid dan reliable dalam penelitian akan membawa hasil yang lebih baik dalam pengumpulan data.

Sfres psikologi diukur dengan menggunakan Depresion Anxiety Stress Scale 42 (DASS 42) yang sudah teruji validitas secara internasional. DASS mempunyai tingkatan discrcrimant validity. Kuesioner stress tidak dilakukan uji reliabilitas karena kuesioner sudah berlaku secara internasional. Kuesioner yang digunakan dalam penelitian ini adalah Depresion Anxiety Stress Scale 42 (DASS 42) yang diformulasikan oleh Lovibond (1995) dengan nilai reliabilitas $(\mathrm{a}=$ 9483). Untuk mengukur tingkat sfres perawat di ruang kritis digunakan scale stress yang berjumlah 42 pertanyaan. Kuesioner telah diterjemahkan oleh Purwati pada tahun 2012 dengan hasil uji validitas $(0,361-0,603)$ dan reliabilitas 0,916 .

\section{HASIL}

Data yang telah diperoleh dari 69 subjek penelitian yang terdiri dari 23 subjek pada ICU, 16 subjek pada HCU, 14 subjek pada NICU, dan 16 subjek pada IGD dianalisis dan diinterpretasikan sesuai dengan keempat identifikasi masalah.

Berdasarkan nilai mean tingkat stress berdasarkan unit yaitu dan 30,62 yaitu stress parah pada unit IGD, 25,62 yaitu tingkat stress parah pada unit HCU, tingkat stress pada setiap unit adalah 21,26 yaitu tingkat sü•ess sedang pada unit ICU, dan 14,07 yaitu stress ringan pada unit NICU. Analisis dari uji statistik data di atas menunjukkan bahwa pada tingkat stress yang tertinggi berdasarkan unit keperawatan kritis di Rumah Sakit Advent Bandung adalah unit IGD dengan nilai 30,62.

Analisa di atas dan tabel 4.2. dapat menyimpulkan bahwa nilai mean tingkat stress berdasarkan posisi yaitu, 24,67 yaitu tingkat stress sedang pada supervisior, 19,94 yaitu tingkat sedang pada head nurse, dan 24,02 tingkat stress pada staff nurse.

Analisis dari uji statistik data di atas menunjukkan bahwa pada tingkat stress 
yang tertinggi berdasarkan posisi keperawatan kritis di Rumah Sakit Advent Bandung adalah posisi supervisor dengan nilai 24,67.

Nilai mean tingkat stress berdasarkan posisi yaitu, yang bekerja pada 1-5 tahun mengalami tigkat stress yang parah $(25,59)$ yang bekerja pada $6-10$ tahun mengalami tingkat stress sedang $(21,56)$, yang bekerja 11-15 tahun mengalami tingkat ringan $(17,67)$, yang bekerja 16-20 tahun mengalami tingkat stress ringan (18), dan yang bekerja $>20$ tahun mengalami tingkat stress sedang $(24,14)$.

Analisis dari uji statistik data di atas menunjukkan bahwa pada tingkat stress yang tertinggi berdasarkan jenjang kair keperawatan kritis di Rumah Sakit Advent Bandung adalah yang bekerja pada 1-5 tahun mengalami tingkat stress yang parah $(25,59)$.

Analisa data diatas, dapat dilihat bahwa nilai signifikan pada tingkat stress berdasarkan unit yaitu $0,298=>0,05$ dapat disimpulkan bahwa tidak ada hubungan stress dengan unit kerja, berdasarkan posisi yaitu 0,606 => 0,05 dapat disimpulkan tidakada hubungan stress dengan posisi kerja, dan dapat dilihat bahwa nilai signifikan pada tingkat stress berdasarkan jenjang karir yaitu $0,058=>$ 0,05 dapat disimpulkan tidak ada cukup bukti untuk menolak Ho, hipotesis jenjang karir tidak memiliki hubungan yang signifikan dengan tingkat stress

\section{PEMBAHASAN}

Tingkat stress yang dialami oleh perawat Instalasi Gawat Darurat dan Unit Rawat Inap berbeda, yaitu perawat Instalasi Gawat Darurat mengalami sfres lebih tinggi dari pada perawat Unit Rawat Inap, sebagian besar perawat Instalasi Gawat Darurat mengalami stress ringan dan perawat Unit Rawat Inap sebagian besar tidak mengalami sfres (Mulyadi, 2015).

Robbins (2006) menyatakan bahwa terdapat hubungan yang erat antara stress dengan kinerja. Pada tahapan tertentu stress akan meningkatkan kinerja karyawan, namun dengan semakin tinggi tingkatan akan berdampak pada menurunnya kinerja karyawan. Gejala yang disebabkan oleh stress adalah pada perilaku karyawan. Indikasinya antara lain menurunnya produktivitas, meningkatnya absensi, perputaran tenaga kerja semakin tinggi. Sfres adalah faktor yang menentukan di tempat kerja dan semakin tinggi jabatan seseorang akan semakin tinggi pula tingkat stres nya. Manager yang menganggap pihak lain sebagai individu dan tidak sekedar memandang mereka sebagai bagian yang dapat dipertukarkan dapat mengurangi tekanan itu membuat tempat kerja menjadi sumber sfres (Anwar, 2000).

Tugas dan tanggung jawab perawat bukan hal yang ringan untuk dipikul, disatu Sisi perawat bertanggungjawab terhadap tugas fisik, 5 dministrative, dari instansi tempat ia bekerja, menghadapi kecemasan, keluhan dan mekanisme pertahanan diri pasien yang muncul pada pasien akibat sakimya, ketegangan pasien dalam kondisi yang menderita sakit kritis atau keadaan terminal, di Sisi lain ia dituntut untuk selalu tampil sebagai profil perawat yang baik oleh pasiennya (Danang, 2009). Novice adalah dimana perawat belum mempunyai pengalaman sama sekali di setiap situasi yang terdapat di rumah sakit, dan biasanya dibawah bimbingan pengawas (Tomey, 1994)

Pekerjaan diartikan sebagai suatu posisi jabatan yang diberikan atau ditugaskan, serta ada keterkaitan hubungan anatara atasan dan bawahan, dan mendapatkan imabalm berupa uang, H.Simamora (2013).

Hubungan tingkat stress berdasarkan unit, posisi, dan jenjang karir yang tidak signifikan ini dapat dipengaruhi oleh jumlah sampel penelitian yang tidak lengkap. Penelitian yang dilakukan pada 69 subjek yang dibagi atas empat unit ini juga berpotensi memiliki perbedaan yang signifikan bila lebih spesifik dalam pernilihan unit. Hubungan tingkat 
stres yang tidak signifikan berdasarkan unit, posisi, dan jenjang karir juga dikarenakan subjek penelitian tidak homogen. Lima sumber stres kerja perawat secara umum adalah beban kerja berlebih, kesulitan berhubungan dengan staf lain, kesulitan merawat pasien kritis, berurusan dengan pengobatan dan perawatan pasien dan kegagalan merawat (Abraham \& Shanley, dalam Sunaryo, 2004).

Robbins (2006) menyatakan bahwa terdapat hubungan yang erat antara stress dengan kinerja. Pada tahapan tertentu stress akan meningkatkan kinerja karyawan, namun dengan semakin tinggi tingkatan st•ess akan berdampak pada menurunnya kinerja karyawan. Gejala yang disebabkan oleh stress adalah pada perilaku karyawan. Indikasinya antara lain menurunnya produktivitas, meningkaü»ra absensi, perputaran tenaga kerja semakin tinggi.

\section{KESIMPULAN}

Kesimpulan yang diperoleh dari penelitian yang telah dilakukan dan uji statistik yang digunakan dalam penelitian ini adalah:

1) Tingkat stress perawat di ruang kritis Rumah Sakit Advent berdasarkan unit adalah unit ICU (Intensif Care Unit) termasuk dalam kategori sefres sedang, unit HCU (High Care Unit) termasuk dalam kategori stress parah, unit Nicu (Neonatal Intensive Care Unit) termasuk dalam kategori stress Ringan, dan unit IGD (Instalasi Gawat Darurat) termasuk dalam kategori stress Parah.

2) Tingkat stress perawat di ruang kritis Rumah Sakit Advent berdasarkan Posisi adalah posisi (Supervisior) yang termasuk dalam kategori sfres sedang, posisi (Head Nurse) yang termasuk dalam kategori stress sedang, dan posisi (Staff Nurse) yang temasuk kategori stress sedang.
3) Tingkat stress perawat di ruang kritis Rumah Sakit Advent berdasarkan Jenjang karir adalah jenjang 1-5 tahun yang termasuk dalam ketegori sü•ess parah, jenjang 6-10 tahun yang termasuk dalam kategori sedang, jenjang 1115 tahun yang termasuk dalam kategori stress ringan, jenjang 16-20 tahun yang termasuk dalam kategori stress ringan, dan jenjang $>20$ tahun yang termasuk dalam kategori stress sedang.

4) Tidak ada cukup bukti untuk menolak Ho, Hipotesis berarti unit, posisi, dan jenjang karir tidak memiliki hubungan yang signifikan dengan tingkat stress.

\section{DAFTAR PUSTAKA}

Akirav, 1., Kozenicky, M., Tal, D, Sandi, C ., Venero, C., \& Richter-Levin, G. (2004). A facilitative role for corticesterone in the acquisition in of a spatial task under moderate stress. Learning \& Memory, 11(2), 188-195.

Alimul Hidayat, A. Aziz (2007) , metode Penelitian Keperawatan dan teknik Analisa Data, Penerbit Salemba medika.

Arwani \& Supriyanto. ( 2006). Manajemen Keperawatan di Bangsal. Jakarta:EGC

Amin, S.M. dan Al-Fandi, H. (2007). Kenapa harus Sfres Terai Sfres Ala Islam, Jakarta: Sinar Grafika

Azwar, A, 1996.Pengantar Ilmu Kesehatan Lingkungan,Penerbit MutiaraSumber Widya, Jakarta

Agung, 2012. Pengaruh Sfres Kerja Terhadap Kinerja Karyawan Pt. 
PIN (persero) Cabang Makasar. Universitas Hasanudin. Available at: ANARUNDANA2012repository.unhas.ac.id

Buzan, Tony. (2010). Buku Pintar Mind Map. Jakarta: PT. Gramedika Pustaka Utama.

Davidoff. 2009. Psikologi Suatu Pengantar. Ditermajahkan oleh Mari Juniati.

Jakarta: Penerbit Erlangga.

Danang Sunyoto, (2012). "Uji Validitas dan Reliabilitas, Asumsi Klasik untuk Kesehatan" Cetakan 1. Yogyakarta: Nuha Medika.

European Foundation For the Improvement of Living and Working Conditions. (2009). Work Related Stress. Irlandia: Eurofound.

Hartono, L. 2007. Stress dan Sfroke. Yogyakarta: Kanisius. Hawari, D. 2001. Manajemen, Cemas dan Depresi. Jakarta: Gaya Baru.

Hidayat, A. 2007. Metode Penelitian Keperawatan dan Teknik Analisis Data. Jakata: Salemba Medika.

Hudak \& Gallo. Perawatan Kritis. Edisi 6. Volume 1. EGC. Jakarta.

Hawari Dadang, Manajemen Sü•es, Cemas dan Depresi, Jakarta: 2001

Ivancevich, J.M, Konopaske, R. Matteson, M.T. 2007. Perilaku dan Manajemen Organisasi. Jilid 1. Edisike tujuh. Jakarta: Erlangga.

Luthans, Fred. 2005. Perilaku Organisasi. Edisi Sepuluh. Diterjemahkan oleh - Vivin Andhika Yuwono; Shekar Purwanti; Th.Arie Prabawati; dan Winong Rosari. Penerbit Andi, Yogyakarta.
Kuncoro, (2005). Sfrategi Bagaimana Meraih KEunggulan Kompetitif. Jakarta: Erlangga.

National Safety Council. T.C. Gilchrest. (2004). Manajemen Alih Bahasa Widyastutik. Jakarta: EGC.

Nanang Martono. 2010. Metode Penelitian Kuantitatif: Analisaisi dan Analisis data sekunder. Jakarta. Raja Grafindo Persada.

Neuron PiramidaldanTebal Lamina Piramidalis CA I Hippocampus padaTikus, Tesis, SekolahPascasarjanaUniversitas Gajah Mada, Yogyakarta.

Ningsih, R. (2011). Efektifitas Paket Pereda Terhadap Intensitas Nyeri pada Remaja Dengan Dismenore Di SMAN Kecamatan CUrup. Penelitian Tesis Keperawatan Maternitas. Universitas Indonesia: Tidak diterbitkan.

Nur, S. (2013). Konflik, Sfres Kerja dan Kepuasan Kerja Pengaruhnya Terhadap Kinerja Pegawai pada Universitas Khairun Ternate.

Nurhayati. 2010. Tesis: Hubungan Pola komunikasi dan Kekuatan Keluarga Dengan Perilaku Seksual Beresiko Pada Remaja di Desa Tridaya Sakti Kecamatan Tambun Selatan Kabupaten Bekasi. Depok: Universitas Indonesia: Fakultas $11 \mathrm{mu} \quad$ Keperawatan

Program Megister $11 \mathrm{mu}$ Keperawatan.

Pitaloka, D. 2010. Sfreskerjaperawat Available [online]:

http://repositorv.usu.ac.id/bitstream 1123456789/28090/1/Append ix.pdf [26 Februari 2013].

Prihatini, L. D. 2008. Hubunganantara Beban KerjadanSfresKerja. Available [online] 
http://repository.usu.ac.id/bitstrea

$\mathrm{m}$

123456789/6899/1/08E00192.pdf

[26 Februari 2013)

Robbins, Stephen. P. 2006.Perilaku Organisasi (alih bahasa Drs. Benjamin Molan), Edisi Bahasa Indonesia, Klaten: PT INT AN SEJATI.

Rice, P.L.(2007). Sfres and Health. Second edition, Wadswoirth, Inc

Setiadi. 2007. Konsep dan penulisan riset keperawatan. Cetakan pertama. Yogyakarta : Graha $11 \mathrm{mu}$.

Simamora, H. 2004 . Manajemen Sumber Daya Manusia. Yogyakarta: STIE YKPN.

Smeltzer, S.C. dan Bare, B.G. (2008). Bunner and Sudarth's textbook Of medical-surgical nursing, terj. Agung. Jakarta: EGC

Tomey .A.M. (1994) . Nursing theorist and their work. Edisi 3.

The Daily. 2007. Work Stress Among Health Care Provider. Available at http:/www.statcan.gc.ca/dailyquotid ien/071113/dq071113aeng.ht $\mathrm{ml}$. [05 November 2015]

Yosep, lyus, 2007, Keperawatanjiwa

(Cetakan 1), Bandung : PT Reflka Aditama

Widodo, 2009. Perbedaan tingkat su•es kerja antara perawat kritis dan perawat gawat darurat di RSUD Dr Moewardi Surakarta. Skripsi.(tidak diterbitkan). Surakarta: Fakultas $11 \mathrm{mu} \quad$ Kesehatan Universitas Muhammadiyah Surakarta. 